\title{
The Birth of Strategic Actors: From Primary to Secondary Temporality
}

\author{
Elke Weik ${ }^{1}$ \\ ${ }^{1}$ Department of Marketing and Management, University of Southern Denmark, Denmark \\ Correspondence: Elke Weik, Department of Marketing and Management, University of Southern Denmark, \\ Campusvej 55, 5230 Odense, Denmark. E-mail: ew@sam.sdu.dk
}

Received: December 16, 2019

Accepted: February 13, 2020

Online Published: February 19, 2020

doi:10.5430/bmr.v9n1p1

URL: https://doi.org/10.5430/bmr.v9n1p1

\begin{abstract}
This paper analyses the emergence of European universities as strategic actors from a temporal perspective. I argue, in line with the literature, that European universities have moved from being institutions to being organisations and, more precisely, organisational actors. I depart from the literature in arguing that this change also has a considerable temporal dimension that has up to now been neglected. The temporal dimension consists in a move from primary temporality, i.e., the making of time, to secondary temporality, i.e., the using of time. In making this argument the paper also responds to calls in the literature to take time more seriously for it shows how temporality constitutes strategic actors, rather than how already established strategic actors use time as a resource.
\end{abstract}

Keywords: temporality; strategic actors, universities, institutions, organizations

\section{Introduction}

There is no doubt that time has always been an important resource in strategy, and timing one of its central activities. Little thought, however, has been given to the manner in which time, and more precisely temporality, enable strategic action in the first place. This paper addresses this gap by arguing that time, rather than being a tool or resource, can also be conceptualised as a precondition for strategizing. In this manner, time can explain how strategic actors emerge.

In making this argument, the paper takes up the call to take time seriously as a fundamental pillar of social construction. There is no dearth of studies on time as a resource, but there is one on time as a perspective of study. This is true for the field of strategy (Bansal \& DesJardine, 2014; Mosakowski \& Earley, 2000) as well as for the wider field of organization studies (Albert, 2013; Hernes, Simpson, \& Soderlund, 2013; Orlikowski \& Yates, 2002; Schultz \& Hernes, 2013). In other words, we should start talking with time, not about time. This is the paper's second contribution.

This paper analyses the trajectory of continental European universities, in particular those in EU countries - from here on, "European universities" -, since the late 1990s. European universities are united by a common history spanning eight centuries and a common model of governance often referred to as the magisterial model, in which academics (the "masters" in medieval parlance) are responsible for organising their university's affairs (Weik, 2014) (Note 1). This common model has come under pressure with the introduction of the Bologna reforms, an EU-wide political and legislative framework coming into effect in 1999. I will provide more detail below.

As a consequence of this, European universities have moved from being institutions to becoming organizations. I will present the argument for this move in the subsequent sections. It entails what I have referred to above as the "birth" of universities as strategic actors, most importantly with regard to their ability to act as competitive producers in a capitalist market.

The move from institution to organisation also implies, however, a change in the temporal framework in which every form of action is embedded. Here is where my analysis of the temporal dimension of the process begins. For I argue that, first, universities underwent a change from primary to secondary temporality. This means they abandoned their own specific temporality for a capitalist temporality in which they became organizational actors. I argue, second, that this temporal change enabled strategic actorhood by providing the opportunity to focus on objective time, an open future and on progress.

I start by introducing the notion of primary temporality and its importance for European universities. I then discuss the transformation of these universities into strategic actors. In a third step, I will how this transformation is based on a transition from primary to secondary temporality, and argue that this transition is indeed a prerequisite for them becoming strategic actors. 


\section{From Institutions to Organisations}

\subsection{Primary and Secondary Temporality}

Temporality refers to the succession of past, present and future. As different from physical time, it involves the understanding of oneself and one's actions in frames that we designate as our past, present and future respectively. The three states overlap and interact as we remember and project (Emirbayer \& Mische, 1998). In this sense, temporality is a deeply social construction. As a social construction, temporality is also always an institutionalised construction, as shared meanings turn into enduring and resilient structures or contexts for action.

Put briefly, primary temporality refers to the making of time, whereas secondary temporality refers to the using of time. In a more sophisticated manner, we can talk of primary temporality as the institutionalisation of a particular form of temporality, for example the temporality of capitalism, and of secondary temporality as the use of this form of temporality, for example in strategizing or accounting.

\subsection{The Primary Temporality of European Universities}

As reference for the primary temporality of European universities, I use the programmatic ideas of Wilhelm von Humboldt (1960) as the most recent explicit formulation. Tasked by the Prussian government to reform higher education, he, together with fellow scholars Johann Gottlieb Fichte and Friedrich Schleiermacher, proposed a model that put universities at the pinnacle of institutionalised education, with other forms (e.g. college, Gymnasium) leading up to it. The model was first implemented with the founding of the University of Berlin (today's Humboldt-Universität) in 1809 and became the universal model of universities in all German speaking countries as well as influencing the university sector in the US (in particular Harvard, Johns Hopkins and Chicago), Japan, Italy, Sweden and England (Collins, 1998). For this reason, it is no exaggeration to say that it has defined the university as an institution in the $20^{\text {th }}$ century. One of its central ideas is the freedom of science (Note 2), in particular from religious and economic interests. Consequently, and in the absence of any religious or economic criteria, the only criterion of scientific quality is the scientificness of the knowledge (Collins, 1998; Huber, 2005) as evaluated by academic peers. This freedom is guaranteed and upheld by the state, who finances universities and takes over many of their administrative tasks. As the individual scholar is free in her or his decisions what to teach and research, the overall organisation is weak; an "organised anarchy", as Cohen, March and Olsen (1972) have called it.

Temporality in this institutional arrangement has some specific qualities. While teaching, to a certain extent, needs to adhere to certain synchronisation demands and hence requires standardisation through timetabling, the content and succession of content is relatively ad hoc as it follows the interests of the researcher. More importantly, however, there is a very different ideal of education in place that produces a very different temporality. The Humboldtian ideal is driven by the idea of "Bildung", a term that is notoriously difficult to translate into English (Koselleck, 2002). While Bildung certainly entails the acquisition of knowledge, it does so with neither a functional nor a pragmatic objective (Koller, 2015). Instead, Bildung has a moral dimension with the aim to enhance a student's humanity and self-actualisation. As such, Bildung is not finished on leaving the university. However, as different from lifelong learning, the idea is not that "society" or "the workplace" demand more and more skills (Humboldt was quite explicit that universities should not provide vocational training), but that human beings grow throughout their lives towards wisdom and moral perfection. The university is one part of this long journey. The temporal implications of such a view are a far more relaxed attitude towards a student's progress through the institution, driven by the knowledge that the university is the start of an ongoing journey of exploration, rather than a self-contained, measurable unit delivering a more or less complete set of "employability" skills.

Time in, and of, research follows an even more individualised pattern: Research takes as long as it takes. If scientificness is the only evaluation criterion, then it is the inherent qualities of research - prominent among them the unpredictability of the outcome - that determine its temporality. Today's standard question of what they will publish in three years' time would have seemed completely ridiculous to scholars throughout the $19^{\text {th }}$ and $20^{\text {th }}$ century.

This self-centred and self-confident constitution of time also constitutes the past in particular ways. With a slower general pace and much fewer publications, the "shelf-life" of an important publication is longer. Tenure, at least for professors, creates a hierarchy of seniority in which past achievements continue to be valued. This, in turn, creates "lineages" where certain perspectives and methodologies are handed down from doctoral "father" to doctoral "son" (traditionally male). Connected to that is the idea that one is part of a certain scholarly tradition that has less to do with one's intellectual choices and more with one's biography.

\subsection{The Institutional Nature of Primary Temporality}

This specific temporality centring on scientificness as the sole value was uphold by a number of institutional devices. I suggest four ways in which temporal frameworks are institutionalised. I do not claim that the list is exhaustive but I would claim that every additional way identified only strengthens my argument. The four devices do not act 
independently of one another. For example, Douglas's argument concerning oppositions relates quite strongly to naturalisation, and naturalisation, in turn, promotes legitimacy. In fact, it is these interdependencies that explain why time is such an extraordinarily stable and powerful construct. The authors cited have discussed these interdependencies in greater detail. I first provide a general description of each device before giving some examples from the Humboldtian university ideal.

\subsubsection{Oppositions}

A central moment of modernity's self-understanding has been its juxtaposition to other, "backward" epochs and cultures. Whether it is its own past depicted as the "Dark Age" or the "Middle Age" or other contemporary cultures that are deemed "primitive" or "unenlightened", modernity has always seen itself at the pinnacle of social evolution. "Future orientation" and "progress" are considered good things in themselves, no matter where they may lead. The ability to link pairs of opposing concepts - as in this case "past-present" and "present-future" with "bad-good" - has been described as the central function of institutions by Mary Douglas (1987). Indeed, she maintains that nothing else but institutions can stipulate the sameness of two conceptual pairs. These analogies serve to legitimise institutions and other societal arrangements, in this case, for example, the institution of science or economic institutions working to bring about "the future".

The Humboldtian university juxtaposed their independent scientific knowledge generation to earlier forms of knowledge creation in the worldly patronage systems of the $17^{\text {th }}$ and $18^{\text {th }}$ century, in which the scholar was dependent on the whims of a particular benefactor, or to the church-dependent variety (Collins, 1998; Huber, 2005).

It also created strong institutional oppositions between academics, in particular professors, and lay persons. Within the university existed a clear hierarchical differentiation between students and academics as well as between junior and senior faculty. Both of these rested (ideally) on scientific expertise and therefore strengthened scientificness as important value.

The central opposition, finally, was between truth and falsehood (Luhmann, 1995), with academics being regarded as "in the truth" and keepers or arbitrators of the truth.

\subsubsection{Naturalisation}

Naturalisation describes the process in which these arbitrary analogies come to be regarded objective and natural (Bourdieu, 1992; Douglas, 1987). Once accomplished, this reduces resistance to the order thus legitimised. Those who still resist can be conveniently labelled "political" acting out of certain "motives", most despicably "self-interest". Bourdieu also discusses the effects on self-identity that such naturalised analogies have. "Become who you are" is, in his eyes, the archetypal demand that institutions express towards individuals underscoring the "natural" nature of these arrangements. This explains, among other factors, why the time of physics has become the dominant conceptualisation considered more natural, objective and primordial than even the basic temporality of past, present and future.

A naturalisation of the above oppositions soon set in. Academics became part of an "eternal" quest for knowledge, and knowledge was solely viewed and accepted in scientific terms. All other forms of knowledge became defined as problematic, speculative, subjective, illusionary - or quite simply as non-knowledge. At the same time, the university as location of scientific knowledge and as institutional pinnacle of formal education became taken for granted as this particular version of history was extended backwards over the 700 years of the university's previous existence. Even today, I would argue, very few people are aware that medieval universities occupied very different places and positions than the Humboldtian university.

\subsubsection{Legitimacy}

The status quo, however, is not only preserved through such naturalised analogies. Weber (1972) points to traditional domination as the ideal type involving the past to legitimise current arrangements. Lineages, national history or a simple "that is how we have always done it", refer to a past that becomes the more mythical the more it is drawn on to legitimise. Since Meyer and Rowan's (1977) seminal contribution we understand that it is not just state actors that desire legitimacy, but that organizations need it as well and organize their operations in accordance. Meyer's later works (J. Meyer, Boli, \& Thomas, 1987; J. Meyer \& Jepperson, 2000; J. W. Meyer, 1996) develop the concept of isomorphism and convergence to maintain that this desire for legitimacy also shapes the legitimacy thus desired, and render it more standardised and more predictable.

Both past and future are mobilised to confer legitimacy. From royal genealogies to successful crisis management, the powerful draw on collective memory of the past to legitimate their authority. Their opponents, on the other hand, use the same tool, just in a different shape. They will often refer either to another past (restoration) or a different future (utopia) (Nowotny, 1975).

Traditions, however, not only legitimise but also give sense to activities and help construe self-identities. They convey values and priorities, for example when the national constitution is celebrated with a holiday, or when Christmas is 
marketed as a special time for the family. Furthermore, there are age limits for sexual consent, full citizenship, etc. which imply a desirability of the states so accessed.

In the case of the university, oppositions and naturalisation also provided legitimacy to the institution and its time conception, as it was considered a world apart with its own values and rules. It is, for example, interesting to see how social status correlated with a chair at a university. Professors were accepted as witnesses and trustees, veritable "pillars of the community". Moreover, academics, as keepers and arbitrators of "the" truth, occupied the role of societal legislators (Bauman, 1995; LeGoff, 1986) or secular priests (Foucault, 1998).

\subsubsection{Norms and Values}

Arguably the most widely discussed aspect of institutions is their normative impact. From the earliest authors (Durkheim, 1976) to neo-institutionalist times, the presence of institutions implies the presence of norms, be they value-based constraints or cognitive frames that select what actors consider feasible, rational and desirable. Examples are minimum age requirements or the "right" time to do something.

Temporality also supports normative integration, as groups intentionally separate themselves from other groups through different time schedules. Zerubavel (1982), for example, presents a study of how the date of Easter was chosen so that it would never coincide with the Jewish Passover, thus avoiding "contagion" of the Christian rite. In a similar way, we, for example, try to keep "work time" out of our "leisure time".

By setting and enforcing norms, by offering legitimacy and by creating analogies between concepts, institutions promote certain values over others. I follow Friedland (2017) in suggesting that these values are indeed at the centre of all institutional efforts, as they define institutional actors and objects or generate institutional practices. Time plays an important role in the attribution of value. Scarcity of time, for example, is a privilege of the powerful - just try to make an appointment with an "important" person. Sacred or festive times are value-laden, and confirm the values they stand for every time they are invoked.

I have referred above to the centrality of truth in academic endeavours. Truth, at least in classic accounts of correspondence theory, and in fact going back to Plato (1993), has the particular quality of being independent of time, as the congruence between propositions and an outside reality is invariable. In this understanding, science progresses towards truth through successive falsification of hypotheses (Popper, 1994). This progress is, however, not measurable, as we do not know its final destination and can therefore not measure the gap to our current state of knowledge.

Other Humboldtian values were humanist in nature, focusing on Bildung and the formation of character, on the value of knowledge in itself and, internally, on proving oneself loyal to traditions, schools and lineages. This, as I have indicated above, fostered a particular relation of past, present and future, as it centred on an accumulation of knowledge and understanding.

\section{Reforms and Strategic Actorhood}

European universities came under pressure as, starting in the 1970s, students turned into student masses. In Germany, for example, student numbers today are eleven times higher than in 1960, while only a handful of new universities have been created since 1980 (Bode, 2016). The steep rise in demand led to internal restructurings, in particular of teaching and examination. The Bologna reform of 1999 added to this process by explicitly introducing competitiveness, self-financing and internationalisation into the political framework regulating universities (Berka, 2008; Brändle, 2010).

A number of authors (most prominently, Brunsson \& Sahlin-Andersson, 2000; De Boer, Enders, \& Leisyte, 2007; Krücken \& Meier, 2006; Ramirez, 2010) have argued that this triggered the conversion from universities as institutions into universities as strategic organisational actors. The desire of the European governments to cope with the increasing complexity of the HE sector through decentralisation, but also the necessity of the HE market to see organisational actors compete in it, paved the way for this transformation process. Its main characteristics were, first, the introduction of accountability, as measured by newly created evaluation, accreditation and auditing systems; second, the definition of organisational goals derived from an organisational self-interest and handed down to lower units in the university; third, the elaboration of a formal structure that included a more pronounced and differentiated hierarchy as well as the inclusion of a number of new functions (e.g. technology transfer, employer engagement, psychological counselling); and, finally, the development of a new HE management profession with its own associations, scholarship and forms of communication.

These measures rendered European universities independent, sovereign actors with clear boundaries, an organisational identity as well as self-interested goals, employing rational means, commanding independent resources and subject to external evaluation. It is easy to see how these characteristics relate to the new organisations' capacity for strategic action. What is less obvious is how it relates to the new organisations' change in temporality. 
In what follows, I first give a brief introduction to secondary temporality before explaining how it is linked to strategic actorhood.

\subsection{Secondary Temporality in Strategic Management Studies}

Juxtaposed to the making of time is individual actors' usage of time within those time frames. The use of time is the classic domain of management and organisation studies. Within the field of strategy more particular, the review of the $20^{\text {th }}$ century literature by Mosakowski and Earley (2000) shows that strategy research rarely treats time as a causal variable and more as a methodological proxy and overwhelmingly conceptualises it as objective physical time with equal and comparable units. While the older literature tends to use time in models of evolution, life cycles or stages, the literature of the 1990s conceptualises strategy more as a disruptive venture that has, by definition, little to do with the past and projects into an unknowable future. Past and future are discussed mostly in terms of short-term vs long-term orientation or in relation to dynamic capabilities.

The new century has brought some closer attention to time, for example the conceptualisation of attention structure through polychronicity (Souitaris \& Maestro, 2010), the impact of long-term versus short-term planning on strategic outcomes (Crilly, 2017; Flammer \& Bansal, 2017), the relation between temporal vagueness, distance and frequency in competition discourses and the response speed of competitors (Nadkarni, Pan, \& Chen, 2019), how a different tolerance for uncertainty, planning horizons, and drawing on the past influences response to climate change (Slawinski \& Bansal, 2012), or how the temporal framing of problems influences chance of making strategic decisions and the scope of change (radical vs. moderate) they trigger (Kaplan \& Orlikowski, 2013). These comparatively few studies still stand, however, in marked contrast to the theoretical importance of time, as Bansal and DesJardine observe in 2012 (Bansal \& DesJardine, 2014). In this regard, strategy research does not differ from research in organisation studies overall (Hernes, et al., 2013; Schultz \& Hernes, 2013).

What these studies show is how organisations and their actors make use of existing time conceptualisations. Actors often do so without reflection, for example when using physical time as if it was the only possible conceptualisation, but also sometimes with an awareness that alternative conceptualisations exist, especially when we look at studies of diverse time frames in organisations. What they do not do, however, is make these time frames as the four ways described above lie well beyond their agential capacity.

\subsection{The Birth of Strategic Actorhood as a Move From Primary to Secondary Temporality}

The argument I am presenting in this section is based on a reversal of the preceding sentence. If strategic actors cannot make time but use time, then the birth of a strategic actor must lie in the transition from making to using time, or from primary to secondary temporality. I have explained above how European universities became strategic actors. As such they make use of the Western capitalist temporality while abandoning their own primary temporality. Let me explain in more detail.

I will focus on three fundamental characteristics of capitalist temporality (Hassard, 1989, 1991; Starkey, 1989; Thompson, 1967). The first is the treatment of time as a homogeneous, objectively measurable commodity that can be used (up) and has a price. This is aptly captured by the phrase "time is money". Temporality, in this frame, is reduced to clock time. The second is the conceptualisation of the future as open but something that can be shaped. In order to achieve the latter, predictability is a central requirement. Predictability is generated by a number of means, but not least by the abovementioned homogeneity of time. Time, in this conceptualisation, is a dimension that always looks the same. As predictability decreases as we move away from the present, capitalist temporality tends to favour a short-term perspective in which predictability is ensured. The past, in contrast, is finished. It may provide data for extrapolation, but beyond that it does not really come into play. It cannot, because this would constrain the desired openness and malleability of the future. Capitalist temporality achieves this, most prominently, by employing the notion of progress. Progress implies the binary opposition of a "bad" past that needs to be overcome or at least improved versus a "good" future in which the improvement will happen. It also implies that change is necessary, which gives heightened importance to strategic planning. The present, finally, plays only a role as a point of departure, a space in which to ready your tools for venturing into the future.

Strategic actorhood is pivotal in this capitalist timeframe for it is the most visible player working to bring about a new, desired future with the help of prediction and the use of time as a resource. Universities, as newly emerging strategic actors, are abandoning their own institutional temporality in favour of a capitalist temporality.

As such, they start thinking in terms of, and evaluating their processes in terms of, the time it takes to sell knowledge (e.g., How long does it take to prepare a lecture? Can some of the teaching be done by cheaper employees? Which exam style minimizes marking time?) as well as the time it takes to produce it (e.g., How many publications should one academic churn out in an x-year period? From which moment in its publication process can a publication be counted?). Teaching itself is transformed into measurable "skills" that promise "employability" at the end of the study programme. The old process of Bildung is split into many small modules with their own measurable and predictable time scheme. 
The consumption of the good "knowledge" (a clearly demarcated thing) is promoted by obsolescence of any knowledge that went before.

The past is discounted as academic biographies and identities become subject to continuous re-evaluation and anything that has been achieved five or seven years ago "counts" no longer. The expectation is that the academic, just like a machine, spouts out the same amount of goods between the age of 35 and 68.

In conversations with colleagues in European universities, I could observe how references to the past sometimes took on an almost mythical quality. When academics talk about their work practices of 15-20 years ago, it is with the undertone of remembering a categorically different time that has no bearing on the present: "Back in the days, we were able to ..." This is a categorical juxtaposition, not a past that could be revisited or mobilised.

In contrast, the future receives all the attention. This is most visible in the amount of hyperbole that goes into the description of the university's plans invariably invoking "excellence", "world leadership" or "cutting-edge science". Strategic plans are continuously devised and revised to specify measurable key performance indicators towards which teaching and research must aspire. Whole new administrative units are created with an eye to providing the means to reach new strategic goals, running predictions, market plans etc. In Germany in 2010 , for example, more than $70 \%$ of the universities had created new administrative jobs to legitimise towards, and communicate with, external stakeholders in the previous decade (Kloke, Blümel, \& Krücken, 2010).

The notion of progress embodied in such practices differs, it should be stressed, rather markedly from Humboldtian ideas concerning the progress of science and humankind. The major distinctive elements are, first, its short-termism, second, its relation to and individual university's life-span, and third, its conceptualisation through measurable proxies (KPIs) within a given time span - all of which are temporal in nature.

The obliteration of the past and emphasis of the future also has consequences for the present. It seems to change its character and shrink (Brüngel, 1995; Lübbe, 1989) or stand still (Rosa, 2015). For example, the traditional rotation of authority that turned professors into deans and back again is broken by bringing in professional deans whose sole function is strategizing. In this manner, what used to be a cyclical temporality is rendered linear and open to progress. Each of the deans, as they come in, has no choice but to adhere to the capitalist framework and present their own deanship as the start of something new and better. In consequence, the present becomes a time in which the old (initiated by the predecessor) is dismantled and the structures for the new are prepared. In a more or less quick succession of deans, the present thus becomes a permanent state of liminality in which the past is finished but the future never really arrives.

Competition, finally, takes on a new dimension, as it becomes a competition of organizations rather than individual scholars. This requires an internal restructuring in which power shifts to the top management and the peer structures of administration are successively abandoned. This is mainly a consequence of an increased speed of competition in a market in which strategic actors now move purposively and decisively. In contrast to the old form of competition between individual academics' prestige and standing in their scientific communities, the new form of competition is far more co-ordinated, focused and, most importantly, faster.

\section{Conclusion}

As indicated at the beginning, this paper had a twofold purpose. The first was to show how European universities became strategic actors by moving from a primary to a secondary temporality. Using the Humboldtian university, I have shown how this form produced and maintained its own institutionalised version of primary temporality through creating time-relevant oppositions, naturalisations, legitimations, norms and values. I have then discussed how the Bologna reforms forced European universities to abandon this primary temporality in order to become strategic organizational actors using a given, in this case capitalist, temporal frame.

The second, more general, purpose of the paper was to show how we can theorise with time and temporality rather than just about them. By studying temporalities, we gain insights into the constitution of social phenomena, in this case, strategic actors. In this understanding, actors are not pre-constituted beings that then use time as a resource, but are temporal in nature. This implies that a shift in temporality changes their nature as actors.

\section{References}

Albert, S. (2013). When. The Art of Perfect Timing. San Francisco: Jossey-Bass.

Bansal, P., \& DesJardine, M. R. (2014). Business sustainability: It is about time. Strategic Organization, 12(1), 70-78. https://doi.org/10.1177/1476127013520265

Bauman, Z. (1995). Legislators and Interpreters. Cambridge: Polity Press.

Berka, W. (2008). Die Quadratur des Kreises: Universitätsautonomie und Wissenschaftsfreiheit. Zeitschrift für Hochschulrecht, 7, 37-48. https://doi.org/10.1007/s00741-008-0168-5 
Bode, C. (2016). Annotated Charts on Germany's Higher Education and Research System. Bonn: Deutscher Akademischer Austauschdienst.

Bourdieu, P. (1992). Language and Symbolic Power. Cambridge: Polity Press.

Brändle, T. (2010). 10 Jahre Bologna-Prozess. Wiesbaden: VS Verlag für Sozialwissenschaften. https://doi.org/10.1007/978-3-531-92203-4

Brüngel, F. (1995). Gedächtnis und Zeitfigurationen. Zur Diagnose und Therapie modernen Zeitbewußtseins. In K. Platt \& M. Dabag (Eds.), Generation und Gedächtnis (pp. 284-304). Berlin: Springer. https://doi.org/10.1007/978-3-322-95972-0_12

Brunsson, N., \& Sahlin-Andersson, K. (2000). Constructing organizations: The example of public sector reform. Organization Studies, 21(4), 721-746. https://doi.org/10.1177/0170840600214003

Cohen, M. D., March, J. G., \& Olsen, J. P. (1972). A garbage can model of organizational choice. Administrative Science Quarterly, 17(1), 1-25. https://doi.org/10.2307/2392088

Collins, R. (1998). The Sociology of Philosophies. Cambridge (Mass.): Harvard University Press.

Crilly, D. (2017). Time and space in strategy discourse: Implications for intertemporal choice. Strategic Management Journal, 38(12), 2370-2389. https://doi.org/10.1002/smj.2687

De Boer, H. F., Enders, J., \& Leisyte, L. (2007). Public sector reform in Dutch higher education: The organizational transformation of the university. Public Administration, 85(1), 27-46. https://doi.org/10.1111/j.1467-9299.2007.00632.x

Douglas, M. (1987). How Institutions Think. London: Routledge \& Kegan.

Durkheim, E. (1976). The Elementary Forms of the Religious Life. London: George Allen \& Unwin.

Emirbayer, M., \& Mische, A. (1998). What Is Agency? American Journal of Sociology, 103(4), 962-1023. https://doi.org/10.1086/231294

Flammer, C., \& Bansal, P. (2017). Does a long-term orientation create value? Evidence from a regression discontinuity. Strategic Management Journal, 38(9), 1827-1847. https://doi.org/10.1002/smj.2629

Foucault, M. (1998). The Will to Knowledge. London: Penguin.

Friedland, R. (2017). The Value of Institutional Logics. In G. Krücken, C. Mazza, R. Meyer \& P. Walgenbach (Eds.), New Themes in Institutional Analysis: Topics and Issues from European Research (pp. 12-50): Edward Elgar.

Hassard, J. (1989). Time and Industrial Sociology. In P. Blyton, J. Hassard, S. Hill \& K. Starkey (Eds.), Time, Work and Organization (pp. 13-34). London: Routledge. https://doi.org/10.4324/9781315267272-2

Hassard, J. (1991). Aspects of Time in Organization. Human Relations, 44(2), 105-126. https://doi.org/10.1177/001872679104400201

Hernes, T., Simpson, B., \& Soderlund, J. (2013). Managing and temporality. Scandinavian Journal of Management, 29(1), 1-6. https://doi.org/10.1016/j.scaman.2012.11.008

Huber, M. (2005). Reform in Deutschland. Soziologie, 34(4), 391-403. https://doi.org/10.1007/s11617-005-0210-1

Kaplan, S., \& Orlikowski, W. J. (2013). Temporal work in strategy making. Organization Science, 24(4), 965-995. https://doi.org/10.1287/orsc. 1120.0792

Kloke, K., Blümel, A., \& Krücken, G. (2010). Hochschulmanagement-Auf dem Weg zu einer neuen Profession? WSI-Mitteilungen, 63(5), 234-241. https://doi.org/10.5771/0342-300X-2010-5-234

Koller, H. C. (2015). Bildung (an) der Universität? In A. Liesner \& O. Sanders (Eds.), Bildung der Universität (pp. 79-100). Bielefeld: transcript.

Koselleck, R. (2002). On the Anthropological and Semantic Structure of "Bildung". In R. Koselleck (Ed.), The Practice of Conceptual History (pp. 170-207). Stanford: Stanford University Press.

Krücken, G., \& Meier, F. (2006). Turning the university into an organizational actor. Globalization and organization: World society and organizational change, 241-257.

LeGoff, J. (1986). Die Intellektuellen im Mittelalter. Stuttgart: Klett-Cotta.

Lübbe, H. (1989). Zeit-Verhältnisse. Über die veränderte Gegenwart von Zukunft und Vergangenheit. In R. Wendorff (Ed.), Im Netz der Zeit (pp. 140-148). Stuttgart: Hirzel.

Luhmann, N. (1995). Social Systems. Palo Alto: Stanford University Press. 
Meyer, J., Boli, J., \& Thomas, G. (1987). Ontology and Rationalization in the Western Cultural Account. In G. Thomas, J. Meyer, F. O. Ramirez \& J. Boli (Eds.), Institutional Structure (pp. 12-37). Newbury Park: Sage.

Meyer, J., \& Jepperson, R. (2000). The 'Actors' of Modern Society: The Cultural Construction of Social Agency. Sociological Theory, 18(1), 100-120. https://doi.org/10.1111/0735-2751.00090

Meyer, J. W. (1996). Otherhood: The promulgation and transmission of ideas in the modern organizational environment. In B. Czarniawska \& B. Joerges (Eds.), Translating organizational change (pp. 241-252).

Meyer, J. W., \& Rowan, B. (1977). Institutionalized organizations: Formal structure as myth and ceremony. American Journal of Sociology, 340-363. https://doi.org/10.1086/226550

Mosakowski, E., \& Earley, P. C. (2000). A selective review of time assumptions in strategy research. academy of Management Review, 25(4), 796-812. https://doi.org/10.5465/amr.2000.3707728

Nadkarni, S., Pan, L., \& Chen, T. (2019). Only timeline will tell: Temporal framing of competitive announcements and rivals' responses. Academy of Management Journal, 62(1), 117-143. https://doi.org/10.5465/amj.2015.0304

Nowotny, H. (1975). Time Structuring and Time Measurement: On the Interrelation between Timekeepers and Social Time. In J. T. Fraser \& N. Lawrence (Eds.), The Study of Time (Vol. 2, pp. 325-342). New York: Springer. https://doi.org/10.1007/978-3-642-50121-0_25

Orlikowski, W. J., \& Yates, J. (2002). It's about time: Temporal structuring in organizations. Organization Science, 13(6), 684-700. https://doi.org/10.1287/orsc.13.6.684.501

Plato. (1993). The Republic. In M. Adler (Ed.), Great Books of the Western World (Vol. 6, pp. 295-441). Chicago: Encyclopedia Britannica.

Popper, K. (1994). Vermutungen und Widerlegungen (Vol. 1). Tübingen: J.C.B. Mohr.

Ramirez, F. O. (2010). Accounting for excellence: Transforming universities into organizational actors Higher education, policy, and the global competition phenomenon (pp. 43-58): Springer. https://doi.org/10.1057/9780230106130_4

Rosa, H. (2015). Das Rasen der Ereignisgeschichte und der Stillstand historischer Bewegung. Überlegungen zum Zusammenhang von Sozialen Wandel und Geschichtserfahrung. Divinatio(39-40), 25-47.

Schultz, M., \& Hernes, T. (2013). A Temporal Perspective on Organizational Identity. Organization Science, 24(1), 1-21. https://doi.org/10.1287/orsc. 1110.0731

Slawinski, N., \& Bansal, P. (2012). A matter of time: The temporal perspectives of organizational responses to climate change. Organization Studies, 33(11), 1537-1563. https://doi.org/10.1177/0170840612463319

Souitaris, V., \& Maestro, B. M. (2010). Polychronicity in top management teams: The impact on strategic decision processes and performance of new technology ventures. Strategic Management Journal, 31(6), 652-678. https://doi.org/10.1002/smj.831

Starkey, K. (1989). Time and Work: a Psychological Perspective. In P. Blyton, J. Hassard, S. Hill \& K. Starkey (Eds.), Time, Work and Organization (pp. 35-56). London: Routledge. https://doi.org/10.4324/9781315267272-3

Thompson, E. P. (1967). Time, Work-Discipline, and Industrial Capitalism. Past and Present, 38, 59-97. https://doi.org/10.1093/past/38.1.56

von Humboldt, W. (1960). Werke in fünf Bänden. Darmstadt: Wissenschaftliche Buchgesellschaft.

Weber, M. (1972). Wirtschaft und Gesellschaft. Tübingen: J.C.B. Mohr.

Weik, E. (2014). The Market for Academic Knowledge: Its Historical Emergence and Inherent Tensions. British Journal of Educational Studies, 62(4), 431-447. https://doi.org/10.1080/00071005.2014.935754

Zerubavel, E. (1982). Easter and Passover: On Calendars and Group Identity. American Sociological Review, 47, 284-289. https://doi.org/10.2307/2094969

\section{Notes}

Note 1. We have come to take this model so much for granted that we may find it difficult to imagine any other governance form, but for a considerable time the alternative of a student-led university administration existed, most famously at the University of Bologna.

Note 2. In line with the German and Nordic usage of the word "Wissenschaft", I use the term "science“ as comprising natural sciences as well as social sciences and humanities. 